Przegląd Prawa Konstytucyjnego

-ISSN 2082-1212-

DOI 10.15804/ppk.2014.06.08

$-\mathrm{Nr} 6(22) / 2014-------$

\title{
Recenzja
}

\section{Kierunki zmian pozycji ustrojowej i funkcji Senatu RP, red. Andrzej Bisztyga, Piotr Zientarski, Kancelaria Senatu, Warszawa 2014, ss. 272}

Recenzowana książka jest efektem konferencji pt. Kierunki zmian w pozycji ustrojowej i funkcji Senatu RP, zorganizowanej dnia 15 października 2013 r. w Warszawie przez senackie komisje - Komisję Ustawodawczą oraz Komisję Regulaminową, Etyki i Spraw Senatorskich. Zawarto w niej 16 artykułów dotyczących problematyki drugiej izby parlamentu - zróżnicowanych tematycznie, dotykających istotnych problemów i zagadnień bikameralizmu. Autorzy tych tekstów to prawnicy-konstytucjonaliści z różnych ośrodków uniwersyteckich oraz praktycy. Fakt tak licznego udziału wybitnych znawców prawa konstytucyjnego należy bez wątpienia uznać za znaczący dla wartości recenzowanej publikacji.

Celem konferencji, której efekt stanowi recenzowana publikacja, była wymiana poglądów na temat zmian w ustroju i funkcjonowaniu Senatu oraz poszukiwanie możliwości wzmocnienia pozycji i roli drugiej izby. O randze tego wydarzenia świadczyły: obecność i wystąpienia marszałka Senatu RP Bogdana Borusewicza, prezesa Najwyższej Izby Kontroli Krzysztofa Kwiatkowskiego czy wiceprzewodniczącego Komisji Ustawodawczej Witolda Pahla.

Redaktorzy naukowi publikacji, Andrzej Bisztyga oraz Piotr Zientarski, we wstępie do książki zwracają uwagę, iż ponaddwudziestoletnie dokonania Senatu RP dowiodły, iż jest on instytucją ustrojowo okrzepłą, która zajmu- 
je trwałe miejsce w systemie organów władzy państwowej. Podkreślili oni, iż w trakcie konferencji wybrzmiała jednoznaczna teza o niezbędności funkcjonowania II izby parlamentu i konieczności ustrojowej jej wzmocnienia. Zwrócili również uwagę na fakt, iż niektórzy badacze, pomimo wcześniej krytycznego stosunku wobec przywrócenia Senatu, uznali potrzebę istnienia bikameralizmu w Polsce. Szczególnie ważne jest to, że problematyka Senatu ukazana została w ujęciu dynamicznym - jako efekt ewolucji dokonującej się w ramach procesów o charakterze społeczno-politycznym.

Zastanawiając się nad dalszą ewolucją Senatu, istotnym jest określenie, w oparciu o jakie akty prawne mogłoby się to dokonać. Andrzej Bisztyga proponuje rozróżnienie między zmianami regulacji prawnych dotyczących Senatu, które wymagają zmian w konstytucji, a w konsekwencji - poparcia na poziomie „większości konstytucyjnej”, a tymi, które takich większości nie wymagają. Jest teraz odpowiedni czas „na określenie kierunków zmian pozycji ustrojowej i funkcji Senatu, ale w ramach spójnej wizji ustrojowej” (s. 15).

Kluczowe znaczenie mają kwestie dotyczące kształtu izby wyższej, sposobów jej kształtowania oraz kompetencji. Prof. Bogusław Banaszak, opisując przesłanki istnienia Senatu w Polsce, zwraca uwagę na rolę drugiej izby jako strażnika dobrego prawa, stwierdzając, iż rola ta „nabiera obecnie szczególnego znaczenia po latach złych doświadczeń z jakością prawa stanowionego przez parlament w całym dotychczasowym okresie transformacji ustrojowej. Okazuje się, że Senat staje się nader często ostatnią instytucją służącą poprawieniu uchwalanych przez Sejm ustaw" (s. 19). Autor opiera swoją tezę na analizie danych dotyczących siedmiu zakończonych już kadencji Senatu. Historia pokazuje, iż ważnym stało się umocnienie roli Komisji Ustawodawczej Senatu, która stała się ciałem selekcjonującym wyroki Trybunału Konstytucyjnego, a także koordynującym całość prac przygotowawczych i legislacyjnych Izby dotyczących tzw. materii wykonawczej. Prof. Bogusław Banaszak podkreśla, że „bez inicjatyw ustawodawczych Senatu trudno sobie wyobrazić właściwy proces realizacji orzeczeń TK w sferze prawodawstwa" (s. 24).

W książce zostały zamieszczone również ważne artykuły dot. wyborów do Senatu. W pierwszym z nich Anna Młynarska-Sobaczewska poddaje analizie dwie cechy wyższej izby polskiej parlamentu: responsywność i repre- 
zentatywność. Natomiast drugi artykuł, Krzysztofa Skotnickiego, przedstawia konstytucyjne uwarunkowania wyborów do Senatu, formułując m.in. wniosek, iż odnowa Senatu w dużej mierze zależy od sposobu zmiany jego kreacji. W ocenie autora uwarunkowania tej procedury często są dość lakoniczne i pozostawiają ustawodawcy daleko idącą swobodę jej kształtowania, ma to jednak miejsce w obszarach, które nie mają istotnego znaczenia dla ukształtowania składu tego organu pozwalającego na jego inne funkcjonowanie (s. 64).

Szczególną wartość mają postulaty de lege ferenda, które mogą stanowić cenne źródło analizy i stać się przyczynkiem do dyskusji nad poszczególnymi rozwiązaniami systemowymi. W szczególności dotyczy to postulatów zawartych w artykule Mariusza Jabłońskiego Rola Senatu w procesie inicjowania i zarzadzania referendum ogólnokrajowym - uwagi de lege lata i de lege ferenda oraz artykule Jarosława Szymanka Senat RP. Uwagi de lege ferenda, w którym wyeksponowano propozycje zmian konstytucyjnej pozycji Senatu w Polsce.

W książce starano się ukazać najważniejsze kierunki zmian funkcji Senatu RP poprzez m.in. ukazanie ewolucji funkcji oraz wskazując propozycje nowych funkcji Senatu. Piotr Zientarski wskazał na obszary, w których Senat, $\mathrm{z}$ racji swojego charakteru, winien być organem pełniącym wiodące role, takie jak: wykonywanie orzeczeń Trybunału Konstytucyjnego oraz opieka nad Polonią. Wskazane jest też wzmocnienie roli Senatu w procedurze zmiany konstytucji. Marek Chmaj z kolei wskazuje na kierunki zmian składu liczbowego Sejmu i Senatu. Twierdzi, iż warto rozważyć zmniejszenie liczebności Sejmu do 333 posłów przy jednoczesnym zwiększeniu liczebności Senatu do 111 senatorów (s. 91). Innym kierunkiem może być włączenie do składu Senatu kliku członków stałych ze względu na zajmowane stanowiska, np. I prezesa Sądu Najwyższego czy prezesa Naczelnego Sądu Administracyjnego (s. 92).

Podjęta również została problematyka inicjatywy ustawodawczej przysługującej Senatowi. Jerzy Ciapała dokonał analizy udziału Senatu w stanowieniu ustaw. Natomiast Lech Jamróz, podejmując kwestie ustrojowe, podkreślił problem skrajnie ograniczonych uprawnień ustawodawczych Senatu, a ponadto przedstawił propozycje zmian w zakresie zarówno kompetencji, jak i organizacji Senatu. 
W publikacji poddano refleksji zagadnienie funkcjonowania izby drugiej parlamentu w państwie demokratycznym wraz z omówieniem poszczególnych modeli tej instytucji. Przedmiotem analizy stały się: procedura budżetowa i udział w niej Senatu (Joanna Juchniewicz), model dwuizbowej struktury polskiego parlamentu (Marek Dobrowolski), jak i koncepcja władzy w doktrynie Monteskiusza i Benjamina Constanta (Bogumił Szmulik). Natomiast Radosław Grabowski skupił się na procedurze zmiany konstytucji i instrumentach temu służących.

W książce starano się również przedstawić zagadnienie bikameralizmu w szerszym kontekście porównawnawczym. Na uwagę zasługuje tu artykuł Jerzego Jaskierni zatytułowany Senat RP a bikameralizm $w$ systemie aksjologicznym Rady Europy. Autor, dokonując analizy systemu aksjologicznego Rady Europy i jej standardów ustrojowych, formułuje tezę, iż „organizacja ta postrzega bikameralizm jako uprawnioną formę ustrojową. Nie przesądza jednak, czy państwa członkowskie powinny po nią sięgać” (s. 212). Podkreślił on też, że choć bikameralizm jest nieodzowny w warunkach państwa federalnego, to jednak jest on niewątpliwie czynnikiem umocnienia podziału władzy i w tym kontekście staje się - w ocenie Rady Europy - istotną wartością (s. 211).

Specyfika funkcjonowania izby wyższej wydobyta została dobitnie na przykładzie Irlandii przez Sabinę Grabowską. Zwróciła ona uwagę na sposób wyłonienia składu Senatu Republiki Irlandii. Podjęła też kwestię roli obywateli w referendum w podejmowaniu decyzji o wprowadzeniu zmian w konstytucji.

Już ta z konieczności selektywna sygnalizacja najważniejszych wątków opracowań zamieszczonych w recenzowanej książce wskazuje, że mamy tu do czynienia z dziełem, które nie tylko wnosi istotny wkład do teorii bikameralizmu, ale też otwiera pole do poszukiwania zmian instytucjonalnych idących w kierunku umocnienia Senatu w polskim systemie ustrojowym. Jeśli bowiem uznamy, że debata o zasadności istnienia drugiej izby w polskim parlamencie została już zakończona, to wciąż otwartym pytaniem pozostaje to, w jaki sposób umocnić usytuowanie Senatu w polskim systemie ustrojowym, by izba ta - niosąca istotny potencjał intelektualny i polityczny - mogła znacząco oddziaływać na bieg spraw państwowych. Należy w związku z tym wyrazić oczekiwanie, że książka ta nie tylko spotka się z szerokim od- 
zewem w środowiskach nauki prawa konstytucyjnego, ale też znajdzie się w polu zainteresowania polityków. Gdyby bowiem doszło do nowelizacji lub zmiany Konstytucji RP, sprawa właściwego doposażenia kompetencyjnego Senatu będzie jednym z oczywistych kierunków potencjalnych zmian. $\mathrm{Z}$ tego punktu widzenia recenzowana książka oferuje wartościowe propozycje de lege fundamentale ferenda, które powinny ukierunkować dalszą debatę $\mathrm{w}$ tej sprawie.

Kamil Spryszak Uniwersytet Jana Kochanowskiego w Kielcach 